\author{
A. Borodin ${ }^{1}$, \\ orcid.org/0000-0002-2872-1008, \\ I. Mityushina ${ }^{2}$, \\ orcid.org/0000-0003-3566-5654
}

1 - Plekhanov Russian University of Economics, Moscow, Russian Federation, e-mail: aib-2004@yandex.ru 2 - Belgorod State National Research University, Belgorod, Russian Federation, e-mail: irenemityshina@mail.ru

\title{
EVALUATING THE EFFECTIVENESS OF COMPANIES USING THE DEA METHOD
}

Purpose. The paper assesses the effectiveness of Russian oil and gas companies. It is hypothesized that the DEA method for evaluating the effectiveness of companies gives the most accurate results compared to the method based on profitability coefficients and allows you to determine the individual and industry-wide effectiveness of companies.

Methodology. The research methodology for testing the hypothesis includes calculating the profitability of oil and gas companies in Russia, as well as classic DEA analysis.

Findings. The empirical base of the study consists of relative and absolute indicators for seven oil and gas companies with the highest revenue in the industry. The result of the study is to confirm the accepted hypothesis and determine the most effective of the studied companies.

Originality. Models for evaluating the performance of companies based on the DEA analysis were developed (at the output of the models there were adopted: revenue, capitalization and oil production). A rating for evaluating the performance of oil and gas companies has been developed, which allowed us to comprehensively characterize the performance of the largest oil and gas companies in Russia (based on the calculation of profitability and technical efficiency indicators), as well as to identify general trends in the industry.

Practical value. The models considered and the results of relative indicators allowed us to conclude that in order to assess the overall performance of companies, it is not enough to analyze individual indicators; moreover, the best result is achieved when building various models that allow a multi-sided approach to the study. The presented models can be recommended for evaluating the performance of companies that belong not only to the oil and gas industry, but also to other industries.

Keywords: company performance, DEA method, profitability indicator, return on equity, return on assets

Introduction. Currently, the processes taking place in the world economy are leading to the onset of a new economic crisis. In Russian reality, the most significant blow is to the oil and gas industry. Starting from January 2020, the price of Brent oil futures began to decline, the strongest decline occurred since mid-February and the price reached its lowest value for several years. The reaction of the oil and gas companies to the current situation and their further actions remain unclear for external users of information. The share price of the oil and gas companies shows the dynamics of falling, for this reason, in the short term, they become unattractive to investors.

The assessment of the company's economic performance is relevant within the framework of an economy that is in a stable state, and during an economic crisis, for the companies themselves when taking further development paths both at the internal level and at the external level. Suppliers of raw materials, customers and investors are also interested in evaluating the company's economic performance. Under current conditions the investors are to the maximum interested in the most accurate assessment of the company's performance, as they seek to make such investments that will not only save money, but also bring significant income with the lowest level of risk.

The oil and gas industry remains the leading industry in Russia (according to the Ministry of Finance for 2019, it accounts for $40 \%$ of GDP) which affects the well-being of the other industries and the overall economic climate in the country. The relevance of the topic is related to the fact that in the current conditions the most accurate assessment of the effectiveness of the oil and gas companies is necessary; this will serve as a starting point for decision-making both for the companies themselves and for other economic entities.

Research into and development of the approaches to evaluating the effectiveness of companies are carried out both at the research level and at the level of directly interested economic entities.

Efficiency can be considered from the point of view of the different aspects; for example, strategic performance of a com-

(C) Borodin A., Mityushina I., 2020 pany takes place which is characterized by three categories: operational efficiency, investment efficiency and financial efficiency. The effectiveness of operating activities is determined by such indicators as sales volume, sales price, volume and share of costs, and productivity.

The effectiveness of investment activity is characterized by the following indicators: the volume and return on investment in production, the volume and return on investment in mergers and acquisitions, research and development, and the brand. In order to assess the effectiveness of financial activities they refer to the indicators of liquidity, the interest rate on loans, and financial leverage.

Literature review. When considering the effectiveness of the company as a whole, we should refer to the effectiveness of management decisions, the effectiveness of product sales, the prospects for production growth, and a high image among customers, contractors and suppliers. The overall economic performance of companies is studied by both Russian and foreign researchers. The research by most scientists-economists in assessing the effectiveness of companies is based on the following approaches.

An assessment of the company's performance characterized by profitability indicators is usually exhaustive only when solving a specific problem. This method is not widely used for analyzing the performance of companies belonging to different industries. Consideration of profitability indicators is most applicable to the overall analysis of the company's financial and economic condition, in comparison with industry-wide average indicators or indicators of similar companies.

The approaches to evaluating the company's performance based on profitability indicators take into account a number of profitability indicators. However, the most commonly used indicators are those of return on assets, that is confirmed by the research by E. Fedorova, and others [1], A. Kurepova and D. Yuva [2], M. Kamande and R. Lokina [3], B. Tuskan and A. Stojanovic [4], M. Dimitric, and co-authors [5], and return on equity, used by the researchers I. Filimonova, I. Komarova [6] and A. Borodin, and other co-authors [7]. When the company's performance is expressed in terms of return on assets, the main focus is on the effectiveness of managing the com- 
pany's assets and their use. If it is a question of return on equity, then the reflection finds efficiency directly for the company's shareholders.

While the use of profitability indicators in evaluating the performance of companies is theoretically justified and practically applicable, a number of significant factors remain unaccounted for. This approach is also not accurate enough due to the fact that, for example, return on assets is an indicator that strongly depends on the industry in which the company operates and its specifics. As a rule, capital-intensive industries are characterized by a lower indicator. Return on assets may be higher for companies operating in the service sector, since they do not need to make large capital investments and finance working capital in large amounts. For these reasons, there is ambiguity in the results obtained, and a careful analysis of the accompanying factors is required [8].

The approach to evaluating the company's performance based on profitability indicators is limited to a set of several indicators presented in the financial statements, and does not take into account a number of other parameters: the level of competition, restrictions on the maximum achievable level of productivity, and so on. A number of researchers in evaluating the performance of companies have not limited themselves to calculating profitability coefficients, they have used the DEA analysis to compare the results obtained using two approaches or supplemented one with the other.

In order to minimize the disadvantages of the approach based on the calculation of relative indicators, the approaches based on evaluating the effectiveness of a number of companies considered simultaneously through the production function are being actively developed in the research works. These methods are usually divided into two groups: parametric (for example, SFA) and nonparametric. The previously mentioned DEA approach (analysis of the operating environment) is a non-parametric approach, it does not explicitly specify the function. The implementation of the DEA method in this study is based on the BCC model which is based on a variable effect from the scale, due to this effect the specifics of each company's activities are taken into account separately. The BCC model is close to reality, the change in indicators at the input and output is disproportionate, and it becomes possible to assess the effectiveness of a large number of companies, since the specifics of the industry to which they belong are taken into account.

As part of the DEA analysis of company performance, there are also several approaches to selecting data for input and output parameters.

The DEA method is actively applied to evaluating the performance of companies that operate in various sectors of the economy. Among the general trends it should be noted that most often these input models include various expenses and natural indicators that express the specifics of companies, and the most common output parameter is revenue. Common features do not mean similarity of methodology in the studies under consideration, each of them has its own individual approach.

In studies where the model has revenue at the output, the difference is both in the input parameters and the implementation of the model itself. A. Grigoriev and L. Otverchenko [9] have applied DEA models: the output-oriented BCC model; the model based on the determination of efficiency reserves the additive DEA model. The researchers have concluded that it is appropriate to use the DEA method for a comparative comprehensive assessment of functioning of the Russian airlines [10]. Fedorova E., and co-authors have used several approaches to evaluate the effectiveness of the companies with foreign direct investments: the calculation of return on assets, the classic DEA method, and the DEA method taking into account the concomitant effects of foreign direct investments. The two hypotheses were tested. The first hypothesis: the international companies are more efficient than the national companies. In order to test the hypothesis, the return on assets was calculated and the DEA method was applied. It was used the FDH and VRS model with a classical approach. The DEA model was also used taking into account related effects. The input data: horizontal co-effect, reverse co-effect, direct coeffect, output revenue. The second hypothesis was: how political uncertainty affected the performance of importing companies. This hypothesis was tested on the basis of the Malmquist index. L. Chien, S. Chi [11], when evaluating the effectiveness of the meat companies, used the DEA analysis based on the data collected through questionnaires. The result of the study is ranking of the companies in order of their performance. The revenues of the meat enterprises were divided into 2 groups: from the auction and slaughter business. It was proved that the high investment capacity of the Taiwanese meat market in the slaughter business is not fully reflected in the revenue. R. Puertas Medina and co-authors [12] have analyzed the approaches to improving efficiency of the textile enterprises. The study provides an assessment of the effectiveness of 85 textile companies. At the first stage, the DEA analysis was conducted to identify any patterns in activity related to the internal characteristics of the firms and their positioning in terms of innovation. Subsequently, truncated regression models were evaluated to determine the aspects that may affect the performance levels of the analyzed companies.

A number of studies have used other revenue indicators instead of output revenue. A. Hosseinzadeh and co-authors [13] analyzed the activities of 33 Australian mining companies determining the gains and losses of their efficiency. The researchers determined which companies improved their performance and which lost their previous positions. For the purpose of the study, variable returns on scale (VRS) were assumed. The result of the study is presented by this conclusion: mining companies could improve their performance between minimum of $17 \%$ in 2010 and maximum of $34 \%$ in 2008, relative to the best performers of practice. M. Garg, S. Garg [14] ranked 12 general insurance companies according to the efficiency obtained using the DEA model over 12 years. The performance of all private sector companies does not fall below the industry average. The private sector insurance companies are beginning to prevail over the state-owned companies, and in the future they have more opportunities to increase efficiency.

The next type of the models used in research is based on the natural indicators (or combination of a natural indicator and revenue) selected at the output. S. Chernov and N. Kolkova [15] in order to determine efficiency of the power grid companies conducted the DEA analysis taking into account the efficiency assessment for CRS and VRS specifications, the scale effect and the nature of return to the "Rts" scale. The scale effect is determined by calculating both CRS and VRS models, then decomposing the performance indicators obtained by the CRS DEA is carried out into the scale and net technical inefficiency. The technical performance assessment of the CRS specification is a multiple of the VRS performance rating and the performance rating scale. Then the companies were grouped by intervals of the values. The conclusions are made about the efficiency of each power grid company and their totality. S. Chao, with co-authors [16] evaluated the efficiency of the container shipping companies. The peculiarity of this study is the decomposition of the process of receiving a service in the form of delivery from a container carrier into several periods. The DEA model was applied in several stages; as a result, the researchers measured the annual performance of the companies and the separation efficiency of the major container carriers. The researchers A. Atris, M. Goto [17] measured unified efficiency by applying non-radial DEA models to a data set. The Kruskal-Wallis sum of ranks test was used to examine whether two types of unified performance indicators change over time and whether there are differences between integrated and independent oil and gas companies. 
This study examines two types of the unified performance indicators-operational and environmental-for 34 USA oil and gas companies over the period of 2011 to 2015. The data set includes seven major oil companies (integrated firms) and 27 independent companies. The results show that the integrated companies have outperformed the independent ones in terms of environmental performance.

The researchers use different coefficients to base the indicators at the output of the DEA model. I. Kolesnev when developing recommendations for improving the efficiency of export-oriented food industry enterprises based on the DEA model, compared actual values of the input indicators with the target ones, determined improved values of the input parameters, and calculated reserves for growth of added value and sales volumes of the inefficient companies [18]. A. Alimkhanova and A. Mizel [19] applied the output-oriented model in the study. The researchers selected indicators that determine the financial and economic activities of the companies as input and output parameters of the model.

The object of the analysis was the gas fuel distribution companies represented by successful enterprises and bankrupt companies. The researchers concluded that the DEA model is applicable for assessing the risk of bankruptcy of enterprises and recommended this approach for other sectors of the economy such as construction, trade, agriculture, catering, and others.

A brief review of studies where evaluation of the companies' performance is given once again proves the applicability of the DEA model for companies belonging to various sectors of the economy. The method is widely used because it allows taking into account a set of factors both relative and absolute indicators, that is, it is not limited by separate values.

Alimkhanova A. and Mizel A. in their research concluded that the DEA analysis is applicable for assessing the bankruptcy of companies in various industries [19]. In the research by E. Fedorova and co-authors, both approaches are used for more complete assessment of the effectiveness of companies: assessment based on profitability and the DEA analysis [1]. B. Tuskan, A. Stojanovic calculated the return on assets and return on equity and compared the obtained indicators with the results of the DEA analysis. The researchers concluded that the DEA method is more effective than the calculation of profitability coefficients, since it allows identifying inefficient companies more quickly [4].

Based on theoretical and empirical research, the following hypothesis was put forward: evaluating the effectiveness of companies based on the DEA analysis is the most objective in comparison with performance analysis based on profitability indicators and allows evaluating the effectiveness of not only an individual company, but also drawing appropriate conclusions for the industry under study.

Thus, the DEA performance assessment should reflect the phenomena occurring in the industry such as impact of an economic crisis.

Methods. In the article the assessment of performance of 7 oil and gas companies selected in accordance with the RBK rating for 2018 in terms of revenue is conducted. The rating consists of the top 500 companies in all sectors of the economy and is presented for 2015 to 2019 . The selected companies for the study ( 7 companies with the highest revenue in the oil and gas industry in 2018) and their revenue are presented in Table 1.

The selected companies meet the following conditions:

1. Companies are active at the time of data collection.

2. Companies are not in the process of bankruptcy.

3 . There are financial and annual reports of the companies for 2014 to 2018.

The studied indicators are: revenue, net profit, net assets, current liquidity ratio, autonomy coefficient, return on assets, return on equity, return on sales, capitalization, oil production volume.
Table 1

Oil and gas companies in the top 500 rating provided by RBK

\begin{tabular}{|c|l|c|c|c|c|}
\hline \multirow{2}{*}{$\begin{array}{c}\text { No. in } \\
\text { the rating }\end{array}$} & \multirow{2}{*}{$\begin{array}{c}\text { Name of the } \\
\text { company }\end{array}$} & \multicolumn{4}{|c|}{ Revenue, billion rubles } \\
\cline { 3 - 6 } & Gazprom & 5477 & 5985 & 5966 & 6546 \\
\hline 1 & Gazpro & 4718 & 5174 & 4744 & 5475 \\
\hline 2 & Lukoil & 3681 & 4120 & 4134 & 5030 \\
\hline 3 & Rosneft & 875 & 993 & 1006 & 1156 \\
\hline 6 & Surgutneftegaz & 757 & 773 & 818 & 854 \\
\hline 13 & Transneft & 476 & 553 & 580 & 681 \\
\hline 14 & Tatneft & 358 & 475 & 537 & 583 \\
\hline 15 & NOVATEK & \multicolumn{4}{|c}{} \\
\hline
\end{tabular}

The research methodology involves the following stages:

1. Calculation of return on assets of the companies.

2. Calculation of return on equity of the companies.

3. Conducting the DEA analysis based on different approaches to selecting input and output indicators.

4. Coordination of the results and formation of the conclusions about the most reliable assessment of companies' performance.

Most often, when analyzing the financial and economic state of a company, the return on assets and return on equity are calculated. Their formulas are correspondingly:

ROA (return on assets) $=$ Net Income/Total Assets,

where Net Income is net profit of a company,

Total Assets are value of assets.

ROE (return on equity) = Net Income/Equity,

where Equity is equity capital of a company.

The practical application of these two indicators is relevant when comparing values for companies within the same industry. The value of indicators is not fixed as a standard, and the company's performance is indicated by their positive and stable or steadily growing value.

These relative indicators do not take into account a number of factors, so we suggest using the DEA model. Using this model, it is possible to evaluate several parameters combined at the input and output. The DEA analysis assumes a system of flexible weights that eliminates the subjective assessment of parameters.

Mathematical record of the BCC model is as follows

$$
e_{0}=\frac{\sum_{j=1}^{s} u_{j} y_{j 0}+u_{0}}{\sum_{i=1}^{r} v_{i} x_{i 0}} \rightarrow \max !
$$

on condition

$$
\frac{\sum_{j=1}^{s} u_{j} y_{j m}+u_{0}}{\sum_{i=1}^{r} v_{i} x_{i m}} \leq 1,
$$

where $u_{j}, v_{i} \geq 0, j=1,2, \ldots, s ; i=1,2, \ldots, r ; u_{0}$ is economy of the scale; $e_{0}$ is the value of the effectiveness of the company under study; $r$ is the number of the input factors, $s$ is the number of the output parameters; $x_{i 0}$ is expression of the input $i$-factor of the company under study; $y_{j 0}$ is expression of the output $j$-parameter of the company under study; $x_{i m}$ is expression of the input $i$-factor of the $m$-company; $y_{j m}$ is expression of the output $j$-parameter of the $m$-company; $v_{i}$ is weighting of the input $i$-factor; $u_{j}$ is weighting of the output $j$-parameter.

The generalized DEA model with standard input and output indicators.

A total of three DEA models were built. The input and output variables for the first model are shown in Fig. 1. 
The choice of parameters for the first model is associated with a well-established approach to determining the effectiveness of companies based on the indicators of financial and economic activity. In the previous studies the relative coefficients are presented mainly as input variables: return on equity and return on non-current capital, but also as output: current liquidity ratio, return on sales.

The second model is focused on evaluating the performance of companies based on the output capitalization indicator (Fig. 2).

This decision has been made because the capitalization reflects the attractiveness of the company to investors. Since all the companies under consideration are public joint-stock companies, it makes sense to talk about their efficiency expressed through maximization of capitalization.

The last DEA model under consideration takes the output value of oil production (Fig. 3). Oil production, its subsequent processing and sale are the basis for the profitability, success and competitiveness of the companies under consideration.

Natural indicators are actively used in the research by a number of scientists-economists: the maximum tonne-kilometer, the number of grid connection points and the amount of electricity released to consumers, the capacity of the fleet and the number of employees, the lifting of ships, the number of wells drilled and carbon dioxide emissions, the number of transactions, the number of commercial entrepreneurs, and the number of slaughter equipment.

Results. At the first stage of the study, the return on assets of the studied companies was calculated, the results are presented in Table 2.

The return on assets of the oil and gas companies for 2014 to 2018 does not have a single trend or any regularities. All indicators by companies for the period under review are positive with the exception of the return on assets of Surgutneftegaz in 2016. A stable trend of changes in indicators

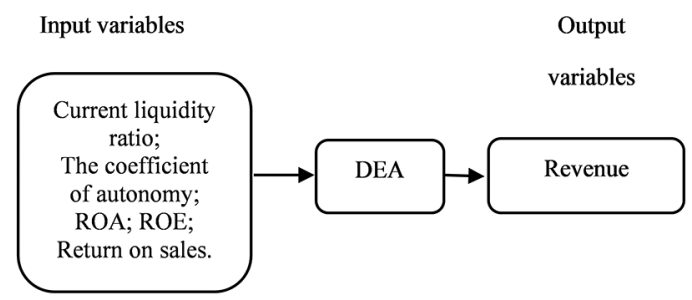

Fig. 1. Parameters of the DEA model based on the relative indicators

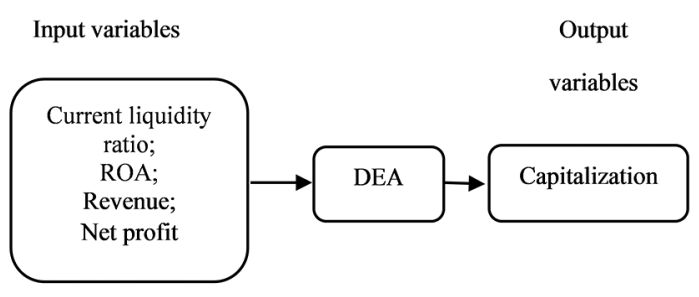

Fig. 2. Parameters of the DEA model with output company capitalization

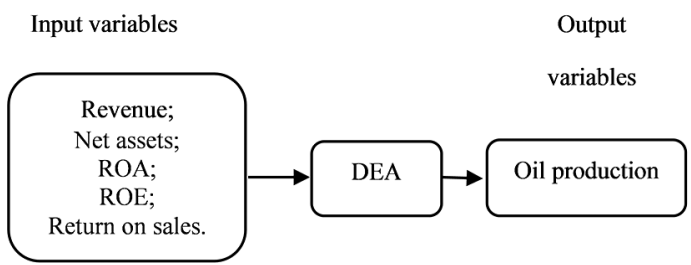

Fig. 3. Parameters of the DEA model with output value of oil production
Table 2

Return on assets of the oil and gas companies for 2014 to $2018, \%$

\begin{tabular}{|l|c|c|c|c|c|}
\hline Company/Year & 2014 & 2015 & 2016 & 2017 & 2018 \\
\hline Gazprom & 1.6 & 3.2 & 3.1 & 0.7 & 6.2 \\
\hline Lukoil & 24.4 & 16 & 9.2 & 10.1 & 10.3 \\
\hline Rosneft & 7.9 & 2.8 & 1.0 & 1.3 & 3.9 \\
\hline Surgutneftegaz & 34.8 & 22.4 & -2.9 & 4.1 & 20.1 \\
\hline Transneft & 1.1 & 1.1 & 2.6 & 5.4 & 1.0 \\
\hline Tatneft & 14.8 & 14 & 15.3 & 13.5 & 24.8 \\
\hline NOVATEK & 9.2 & 15.2 & 24.8 & 19.6 & 22.9 \\
\hline Average & 13.4 & 10.67 & 7.59 & 7.81 & 12.74 \\
\hline
\end{tabular}

while maintaining high values is observed in the companies: Lukoil, Tatneft and NOVATEK. Based on the table data, it is impossible to tell about the company's performance based on data of one year. Thus, in 2014 and 2015, the return on assets of Surgutneftegaz PJSC was the highest in the sample, but in 2016 the indicator turned negative. It is also impossible to draw a conclusion based on this about the company's inefficiency, since in 2017 the value of profitability became positive.

Thus, we see that the obtained indicators of return on assets do not allow us to make full conclusions about the effectiveness of the studied companies. The dynamics of return on assets for the period under review for the companies is heterogeneous, that is, it is not related to the external factors occurring in the world and in the industry but is due to decisions made in the companies themselves.

The next step is to calculate the return on equity, the results are shown in Table 3.

The values of return on equity for the studied companies for 2014 to 2018 are similar to the previously considered indicators of return on assets which presents changes in profitability indicators due to changes in net profit. High values indicate a significant preponderance of net profit over equity of the companies. Based on these indicators, it can be concluded that all companies effectively use their own capital so that is an important result for their owners. Stable high coefficients are observed for companies: NOVATEK, Tatneft and Lukoil, whose return on equity for five years was not less than $14 \%$. Gazprom PJSC is characterized by the lowest return on equity indicators, despite the fact that the company is one of the most attractive companies in Russia for owners.

Thus, the calculated indicators of return on assets and equity of the companies do not allow us to draw full conclu-

Table 3

Return on equity of the oil and gas companies for 2014 to 2018, \%

\begin{tabular}{|l|c|c|c|c|c|}
\hline Company/Year & 2014 & 2015 & 2016 & 2017 & 2018 \\
\hline Gazprom & 2.08 & 4 & 4 & 1 & 9 \\
\hline Lukoil & 37 & 25 & 14 & 15 & 19 \\
\hline Rosneft & 37 & 17 & 7 & 9 & 25 \\
\hline Surgutneftegaz & 37 & 24 & -3 & 4 & 21 \\
\hline Transneft & 8 & 8 & 18 & 32 & 5 \\
\hline Tatneft & 18 & 16 & 18 & 16 & 31 \\
\hline NOVATEK & 18 & 32 & 44 & 28 & 30 \\
\hline Average & 22.44 & 18.0 & 14.57 & 15.0 & 20.0 \\
\hline
\end{tabular}


sions about the effectiveness of the companies. In general, it is possible to talk about the effectiveness of all the companies studied.

In order to get more concrete results, the DEA model was implemented based on relative indicators and output revenue (Table 4).

The data in Table 4 are interpreted unambiguously: over the five years studied, three companies were effective: Gazprom, Rosneft and Transneft. The efficiency of Lukoil PJSC grew steadily and reached its maximum in the last two years under review. Surgutneftegaz PJSC is the most inefficient company in the sample, its growth from 2014 to 2017 is replaced by a sharp drop in 2018.

In accordance with the proposed model, the companies of Tatneft and NOVATEK are characterized by indicators below 0.5 and that indicates the inefficiency of the companies. In this model the result of the average arithmetic value of performance indicators for all companies in the sample is important. It is clear that in 2014, the efficiency is the least, which is explained by the economic crisis of 2014, triggered by the fall in oil prices and the foreign policy situation related to the introduction of sanctions against Russia. In the following years, oil and gas companies adapted to economic trends, and their performance indicators began to increase.

When evaluating the company's performance related to investment attractiveness, special attention should be paid to the size of the company's capitalization; the following model was focused on it (Table 5).

The built model with the capitalization of the companies at the output has showed that the following companies are effective: Rosneft, Transneft, NOVATEK. Gazprom PJSC can be also called as an effective company in the years when the indicators did not take an absolute value of efficiency, they were close to one. Based on the results of two models, Lukoil PJSC is absolutely effective in 2017 and 2018 and is

Table 4

Results of the DEA analysis based on relative indicators for 2014 to 2018

\begin{tabular}{|l|c|c|c|c|c|}
\hline Company/Year & 2014 & 2015 & 2016 & 2017 & 2018 \\
\hline Gazprom & 1.0 & 1.0 & 1.0 & 1.0 & 1.0 \\
\hline Lukoil & 0.40 & 0.62 & 0.69 & 1.0 & 1.0 \\
\hline Rosneft & 1.0 & 1.0 & 1.0 & 1.0 & 1.0 \\
\hline Surgutneftegaz & 0.21 & 0.29 & 0.31 & 0.65 & 0.35 \\
\hline Transneft & 1.0 & 1.0 & 1.0 & 1.0 & 1.0 \\
\hline Tatneft & 0.36 & 0.44 & 0.39 & 0.41 & 0.26 \\
\hline NOVATEK & 0.41 & 0.93 & 0.40 & 0.48 & 0.29 \\
\hline Average & 0.63 & 0.75 & 0.78 & 0.79 & 0.70 \\
\hline
\end{tabular}

\section{Table 5}

Results of the DEA analysis with capitalization of the companies at output for 2014 to 2018

\begin{tabular}{|l|c|c|c|c|c|}
\hline Company/Year & 2014 & 2015 & 2016 & 2017 & 2018 \\
\hline Gazprom & 1.0 & 1.0 & 0.76 & 1.0 & 0.81 \\
\hline Lukoil & 0.98 & 0.85 & 0.91 & 1.0 & 1.0 \\
\hline Rosneft & 1.0 & 1.0 & 1.0 & 1.0 & 1.0 \\
\hline Surgutneftegaz & 0.66 & 0.66 & 0.50 & 0.86 & 0.65 \\
\hline Transneft & 1.0 & 1.0 & 1.0 & 1.0 & 1.0 \\
\hline Tatneft & 0.82 & 0.81 & 0.81 & 0.89 & 0.85 \\
\hline NOVATEK & 1.0 & 1.0 & 1.0 & 1.0 & 1.0 \\
\hline Average & 0.92 & 0.90 & 0.85 & 0.96 & 0.90 \\
\hline
\end{tabular}

characterized by high efficiency during the rest of the study period. Surgutneftegas PJSC has the lowest efficiency in the sample.

There are similar trends among the two DEA models considered.

For completeness of the study, the last step is to conduct the DEA analysis with a focus on the natural indicator, namely, the volume of oil production (Table 6).

As a result, the DEA model focused on the output of oil production showed the effectiveness of all the companies studied. There are minor deviations for a number of companies in different years. Stable absolute efficiency is characteristic of Lukoil PJSC and Transneft JSC. The absolute efficiency of all the companies in the sample for 2017 indicates the success of the industry as a whole in oil production during this period.

Thus, in accordance with the three models built by the DEA, Transneft PJSC and Gazprom PJSC are recognized as the most effective companies. However, it should be noted that all the companies were characterized by high performance indicators in different periods. The lowest efficiency among the companies in the sample belongs to Surgutneftegaz PJSC. Such conclusions could not be made based on the indicators of return on assets and return on equity, which confirms the hypothesis adopted in this study. The DEA model based on relative indicators (input parameters) and the output parameter in the form of revenue allowed determining the overall trend in the industry related to external economic influence.

Conclusions. The article analyzes approaches to evaluating the effectiveness of companies in various industries. These approaches consist of analyzing profitability indicators and evaluating technical efficiency using the DEA method. A number of researchers point out the applicability of the DEA analysis to various sectors of the economy, and also consider this approach to be the most accurate and practical.

It was hypothesized that the evaluation of the performance of the oil and gas companies based on relative indicators is not accurate enough in comparison with the evaluation based on the DEA method which also allows determining industrywide trends. To prove the hypothesis, return on assets and return on equity were calculated for the first seven oil and gas companies in the RBK top 500 rating. Based on the results obtained, it is impractical to draw conclusions about the effectiveness of the companies. So the next step was to perform the DEA analysis by three models.

The considered models and the results of relative indicators allowed concluding that in order to assess the overall performance of companies, it is not enough to analyze individual indicators; moreover, the best result is achieved when building various models that allow a multi-sided approach to the study. As a result of the study, Transneft PJSC and Gazprom PJSC were found to be the most effective.

Table 6

Results of the DEA analysis with the amount of oil produced at the output for 2014 to 2018

\begin{tabular}{|l|c|c|c|c|c|}
\hline Company/Year & 2014 & 2015 & 2016 & 2017 & 2018 \\
\hline Gazprom & 1.0 & 1.0 & 0.81 & 1.0 & 0.78 \\
\hline Lukoil & 1.0 & 1.0 & 1.0 & 1.0 & 1.0 \\
\hline Rosneft & 0.75 & 0.79 & 1.0 & 1.0 & 0.74 \\
\hline Surgutneftegaz & 0.83 & 0.85 & 1.0 & 1.0 & 0.79 \\
\hline Transneft & 1.0 & 1.0 & 1.0 & 1.0 & 1.0 \\
\hline Tatneft & 0.99 & 1.0 & 0.99 & 1.0 & 0.93 \\
\hline NOVATEK & 1.0 & 1.0 & 1.0 & 1.0 & 0.97 \\
\hline Average & 0.94 & 0.95 & 0.97 & 1.0 & 0.89 \\
\hline
\end{tabular}


The presented models can be recommended for evaluating the performance of companies that belong not only to the oil and gas industry but also to others.

Acknowledgments. This article was funded as part of the internal grant under the name "Preparation of scientifically based proposals for the development of the Russian market of financial technologies and alternative money as an element of the country's innovative policy" by PRUE.

\section{References.}

1. Fedorova, E.A., Korkmazova, B. K., \& Muratov, M.A. (2015). Evaluating the effectiveness of companies with foreign direct investment: industry features in the Russian Federation. Prostranstvennaya ekonomika, 2, 47-63. https://doi. org/10.14530/se. 2015. 2. 047-063.

2. Kurepova, A. M., \& Yuva, D. S. (2019). Justification of the choice of indicators for evaluating the performance of companies on the example of the oil and gas industry. Interekspo GEO Sibir, 2(5), 257-265. https://doi.org/10.33764/2618981X-2019-2-5-257-265.

3. Kamande, M., \& Lokina, R. (2013). Clean Production and Profitability: An Eco-efficiency Analysis of Kenyan Manufacturing Firms. Journal of Environment \& Development, 22(2), 169-185. https://doi.org/10.1177/1070496512471948.

4. Tuskan, B., \& Stojanovic, A. (2016). Measurement of cost efficiency in the European banking industry. Croatian Operational Research Review, 7(1), 47-66.

5. Dimitric, M., Tomas Zikovic, I., \& Arbula Blecich, A. (2019). Profitability determinants of hotel companies in selected Mediterranean countries. Economic Research-Ekonomska Istrazivanja, 32(1), 1977-1993. https://doi.org/10.1080/13 31677X.2019.1642785.

6. Filimonova, I. V., \& Komarova, A. V. (2019). Factor analysis of the economic efficiency of the Russian oil and gas industry. Vestnik Permskogo nacionalnogo issledovatelskogo politehnicheskogo universiteta. Socialno-ekonomicheskie nauki, 4, 204-217. https://doi.org/10.15593/2224-9354/2019.4.16.

7. Bondarenko, T., Prodanova, N., Borodin, A., Kokorev, A., \& Kairbekuly, A. (2020). The role of non-financial reporting in corporate sustainability of pharmaceutical industry. Systematic Reviews in Pharmacy, 11(12), 1514-1522. https://doi. org/10.13838/srp.2020.12.223.

8. Vasylieva, T., Jurgilewicz, O., Poliakh, S., Tvaronavičienè, M., \& Hydzik, P. (2020). Problems of measuring country's financial security. Journal of International Studies, 13(2), 329346. https://doi.org/10.14254/2071-8330.2020/13-2/22.

9. Grigoriev, A. N., \& Otverchenko, L. F. (2016). Comprehensive assessment of the airline's performance. Voprosi studencheskoi nauki, 5(5), 19-25.

10. Borodin, A., Ziyadin, S., Islyam, G., \& Panaedova, G. (2020). Impact of mergers and acquisitions on companies' financial performance. Journal of International Studies, 13(2), 34-47. https://doi.org/10.14254/2071-8330.2020/13-2/3.

11. Chien, L., \& Chi, S. (2019). An integrated data envelopment approach for evaluating the meat companies efficiency. Agricultural Economics, 65(10), 470-480. https://doi. org/10.17221/91/2019-AGRICECON.

12. Puertas Medina, R., Martí Selva, M. L., \& Calafat Marzal, C. (2020). An analysis of innovation in textile companies: An efficiency approach. Bulletin of Economic Research, 72(1), 63-76. https://doi.org/10.1111/boer.12210.

13. Hosseinzadeh, A., Smyth, R., Valadkhani, A., \& Le, V. (2016). Analyzing the Efficiency Performance of Major Australian Mining Companies Using Bootstrap Data Envelopment Analysis. Economic Modelling, 57, 26-35. https://doi. org/10.1016/i.econmod.2016.04.008.

14. Garg, M., \& Garg, S. (2020). Efficiency Evaluation of Indian General Insurance Companies IUP. Journal of Management Research, 19(1), 7-26.

15. Chernov, S., \& Kolkova, N. (2019). Determination of the economic efficiency index of electric grid companies based on
DEA analysis. Biznes. Obrazovanie. Pravo, 1(46), 285-292. https://doi.org/10.25683/VOLBI.2019.46.115.

16. Chao, S.-L., Yu, M. M., \& Hsieh, W. F. (2018). Evaluating the efficiency of major container shipping companies: A framework of dynamic network DEA with shared inputs. Transportation Research Part A: Policy and Practice, 117, 44-57. https://doi.org/10.1016/j.tra.2018.08.002.

17. Atris, A., \& Goto, M. (2019). Vertical structure and efficiency assessment of the US oil and gas. Resources Policy, 63, 301-313. https://doi.org/10.1016/j.resourpol.2019.101437.

18. Kolesnev, I. (2018). Recommendations for improving the efficiency of export-oriented food industry enterprises. Agrarnaya ekonomika, 9(280), 32-42.

19. Alimkhanova, A. N., \& Mizel, A.A. (2019). Evaluating the effectiveness of enterprises based on the DEA method. Dokladi Tomskogo gosudarstvennogo universiteta sistem upravleniya i radioelektroniki, 22(2), 104-108. https://doi.org/10.21293/18180442-2019-22-2-104-108.

\section{Оцінка ефективності компаній з використанням методу DEA}

\section{О. І. Бородін ${ }^{1}$, I. Л. Мітюшина}

1 - Російський економічний університет імені Г.В. Плеханова, м. Москва, Російська Федерація, e-mail: aib2004@yandex.ru

2 - Бєлгородський державний національний дослідницький університет, м. Бєлгород, Російська Федерація, e-mail: irenemityshina@mail.ru

Мета. У роботі оцінюється ефективність нафтогазових російських компаній. Висунута гіпотеза про те, що метод DEA при оцінці ефективності компаній дає найбільш точні результати в порівнянні з методом, що грунтується на коефіцієнтах рентабельності та дозволяє визначити індивідуальну й загальногалузеву ефективність компаній.

Методика. Методологія дослідження з метою перевірки гіпотези включає в себе розрахунок рентабельності нафтогазових компаній Росії, а також класичний DEAаналіз.

Результати. Емпірична база дослідження складається з відносних і абсолютних показників по семи нафтогазовим компаніям 3 найбільш високою виручкою в галузі. Результатом дослідження є підтвердження прийнятої гіпотези й визначення найбільш ефективних із досліджуваних компаній.

Наукова новизна. Розроблені моделі оцінки ефективності діяльності компаній на основі DEA-аналізу (на виході моделей були прийняті: виручка, капіталізація та видобуток нафти). Побудовано рейтинг оцінки ефективності діяльності компаній нафтогазової галузі, що дозволив багатосторонньо охарактеризувати ефективність найбільших нафтогазових компаній Росії (на основі розрахунку показників рентабельності й технічної ефективності), а також виявити загальні тенденції в галузі.

Практична значимість. Розглянуті моделі та результати відносних показників дозволили зробити висновок про те, що з метою оцінки загальної ефективності компаній недостатньо аналізу окремих показників, більш того, найкращий результат досягається за побудови різних моделей, що дозволяють багатосторонньо підійти до дослідження. Представлені моделі можуть бути рекомендовані для оцінки ефективності компаній, що відносяться не тільки до нафтогазової галузі, але й до інших галузей.

Ключові слова: ефективність компаній, DEA-метод, коефіцієнт рентабельності, рентабельність власного капіталу, рентабельність активів 


\section{Оценка эффективности компаний с использованием метода DEA}

\section{А. И. Бородин ${ }^{1}$, И. Л. Митюшина ${ }^{2}$}

1 - Российский экономический университет имени Г. В. Плеханова, г. Москва, Российская Федерация, e-mail: aib-2004@yandex.ru

2 - Белгородский государственный национальный исследовательский университет, г. Белгород, Российская Федерация, e-mail: irenemityshina@mail.ru

Цель. В работе оценивается эффективность нефтегазовых российских компаний. Выдвинута гипотеза о том, что метод DEA при оценке эффективности компаний дает наиболее точные результаты по сравнению с методом, основывающемся на коэффициентах рентабельности и позволяет определить индивидуальную и общеотраслевую эффективность компаний.

Методика. Методология исследования в целях проверки гипотезы включает в себя расчет рентабельности нефтегазовых компаний России, а также классический DEA-анализ.

Результаты. Эмпирическая база исследования состоит из относительных и абсолютных показателей по семи нефтегазовым компаниям с наиболее высокой выручкой в отрасли. Результатом исследования является подтверж- дение принятой гипотезы и определение наиболее эффективных из исследуемых компаний.

Научная новизна. Разработаны модели оценки эффективности деятельности компаний на основе DEAанализа (на выходе моделей были приняты: выручка, капитализация и добыча нефти). Построен рейтинг оценки эффективности деятельности компаний нефтегазовой отрасли, который позволил многосторонне охарактеризовать эффективность крупнейших нефтегазовых компаний России (на основе расчета показателей рентабельности и технической эффективности), а также выявить общие тенденции в отрасли.

Практическая значимость. Рассмотренные модели и результаты относительных показателей позволили сделать вывод о том, что с целью оценки общей эффективности компаний недостаточно анализа отдельных показателей, более того, наилучший результат достигается при построении различных моделей, которые позволяют многосторонне подойти к исследованию. Представленные модели могут быть рекомендованы для оценки эффективности компаний, относящихся не только к нефтегазовой отрасли, но и к другим отраслям.

Ключевые слова: эффективность компаний, DEAметод, коэффициент рентабельности, рентабельность собственного капитала, рентабельность активов

Recommended for publication by I. Ilina, Doctor of Economic Sciences. The manuscript was submitted 03.06.20. 